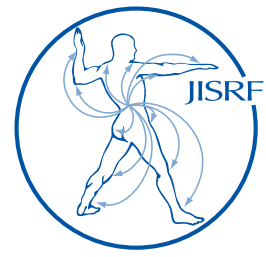

Check for updates

\title{
Third-body Wear Damage Produced in CoCr Surfaces by Hydroxyapatite and Alumina Ceramic Debris: A 10-cycle Metal-on-Metal Simulator Study
}

Halim $T^{1}$, Burgett-Moreno $M^{1}$, Donaldson $T^{1}$, Clarke $I C^{1,2}$

\begin{abstract}
Ceramic particles are believed to be particularly abrasive due to their extreme hardness. Ceramic debris has been reported in retrieved total hip arthroplasty (THA) due to chipping and fracture of alumina components or by flaking of hydroxyapatite from implant coatings. However there appears to be no abrasion ranking of such particle behavior. The hypotheses in this study were, i) alumina particles would create large scratches in $\mathrm{CoCr}$ surfaces and ii) hydroxyapatite would produce very mild scratching comparable to bone-cement particles. Hydroxyapatite beads came in two types of commercial powders while the flakes were scraped from retrieved femoral stems. Alumina beads came in two commercial powders and flakes were retrieved from a fractured ceramic head. Particle morphologies were determined by SEM and $\mathrm{CoCr}$ surface damage by interferometry and SEM. Six 38-mm MOM were mounted inverted in a hip simulator and run with ceramic particles inserted for a 10 -second test. Surface-roughness ranking after 10 -second abrasion test revealed that bone cement and hydroxyapatite produced least damage to $\mathrm{CoCr}$ surfaces while alumina produced the most. Alumina increased surface roughness 19-fold greater than either hydroxyapatite or bone-cement particles. The alumina debris produced numerous scratches typically 20-80 $\mu \mathrm{m}$ wide with some up to $140 \mu \mathrm{m}$ wide. Surprisingly the alumina beads and flakes were pulverized within the 10-second test interval and remained adherent to the CoCr surfaces. Additionally, the hydroxyapatite although also a ceramic had no more effect on $\mathrm{CoCr}$ than the bone-cement debris. Use of wellcharacterized and commercially available alumina and hydroxyapatite powders appeared advantageous for abrasion tests. These new data indicated that such ceramic powders have merit.
\end{abstract}

Keywords: ceramic hydroxyapatite alumina debris $\mathrm{CoCr}$, 3rd-body abrasive wear, MOM hip arthroplasty, simulator Level of Evidence: AAOS Therapeutic Level III

1 Thomas Halim, BSc PhD; Michelle D. Burgett-Moreno, BA; Thomas K. Donaldson, MD - Donaldson Arthritis Research Foundation, 900 E. Washington Street, Suite 200 Colton, CA 92324 US

2 Ian C. Clarke, BSc PhD - Orthopedic Research, Department of Orthopedics, LLUMC, Rehabilitation Building, 11406 Loma Linda Drive, Loma Linda University, Loma Linda, CA 92354, US.

(Direct reprint requests to Ian C Clarke, email: ithipgeek15@yahoo.com)
(C) 2015 Halim, Burgett-Moreno, Donaldson, Clarke. All rights reserved Authors retain copyright and grant the journal right of first publication with the work Reconstructive Review follows the Creative Commons Attribution-NonCommercial CC BY-NC. This license allows anyone to download works, build upon the material, and share them with others for non-commercial purposes as long as they credit the senior author, Reconstructive Review, and the Joint Implant Surgery \& Research Foundation (JISRF). An example credit would be: "Courtesy of (senior author's name), Reconstructive Review, JISRF, Chagrin Falls, Ohio". 


\section{Introduction}

There are many risks in total hip arthroplasty (THA) that may trigger adverse wear, including; impingement, $[1,2]$ subluxation, $[3,4]$ dislocation, [5,6] "edge wear", [79] and micro-separation. [10-12] Unfortunately there is little understanding with regard to which patients may be at risk [5,6,13-21] and uncertainty as to which events may trigger a major particle release. [22,23] Acetabular cups combined with metal and ceramic liners may incur additional risks due to, (a) the cup rim plastically deforming the femoral head, [24] (b) 3rd-body abrasion created by liberated metal particles, $[25,26]$ and (c) smearing of metal alloy contaminants onto $\mathrm{CoCr}$ bearings. [6,27] There are also varying opinions on how hard a particle has to be to damage metallic bearings (Fig.1 ). These data are important for understanding material interactions between hard particles, [28,29] designing laboratory wear studies, [30$34]$ and understanding the implications of 3rd-body wear in vivo. $[3,12,25,26,35]$

Abrasion models have included a) particles inserted between bearing surfaces, $[29,30]$ b) particles added to lubricants to produce abrasive slurries, $[31,32,34,36-38]$ and c) mathematical modeling of debris interactions. [28,29] A MOM simulator study introduced titanium (Ti) particulates [30] that dramatically increased wear rates. Another study used a high concentration of hydroxyapatite powder (HA) in the test lubricant but this had no measurable effect on MOM wear. [31] Our prior simulator study contrasted abrasion potential of large particles of $\mathrm{CoCr}$ and Ti6Al4V versus bone-cement flakes (PMMA) in a 10-second simulator test. [39] The large PMMA particles had no visible effect on $\mathrm{CoCr}$ surfaces whereas the metal debris increased surface roughness by approximately 20 -fold. The resulting scratch profiles ranging 20-108 $\mu \mathrm{m}$ wide and 0.5 $2.8 \mu \mathrm{m}$ deep. The scratch aspect ratio (Fig. 2) averaged 0.3 , indicating that the large metal particles had plastically deformed to create wide but shallow scratches in $\mathrm{CoCr}$ surfaces. Such abrasion tracks appeared identical to those reported on retrieved MOM bearings. [25] Ti6Al4V particles produced abrasion tracks similar to $\mathrm{CoCr}$ particles but also clearly demonstrated an ability to fragment and adhere to CoCr surfaces. [39] Such varied debris interactions in MOM bearings illustrated that we have little understanding of the life history of debris that circulates in the human hip joint.

The aim of this study was to characterize 3rd-body abrasion effects of ceramic particulates in MOM bearings. Ceramic debris has been reported in retrieved THA, either from implant coatings such as hydroxyapatite [40$46]$ or following chipping or fracture of alumina compo-

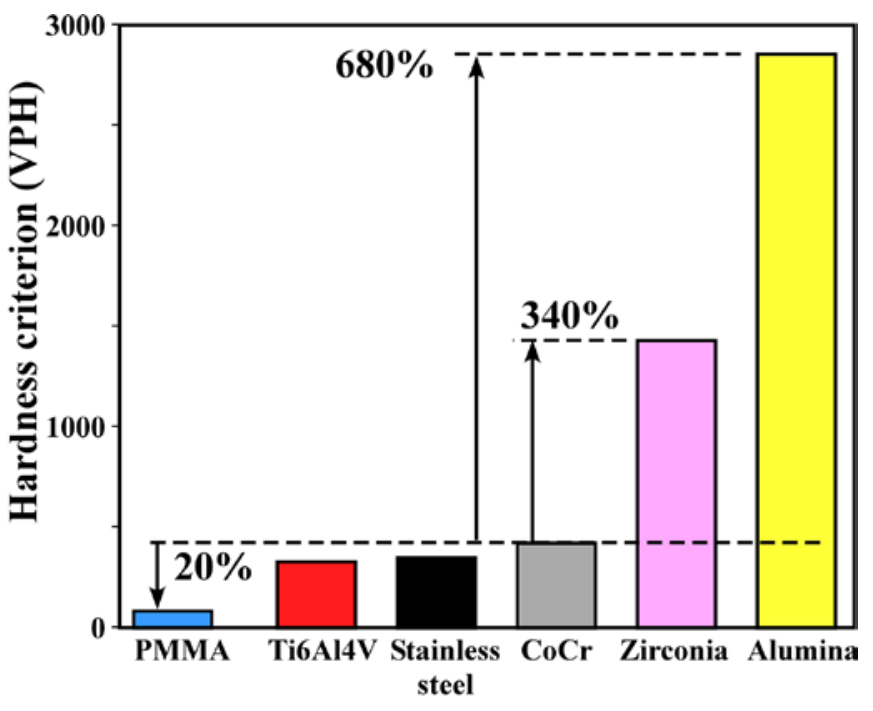

Figure 1. Ranking of material hardness for bone cement, metal alloys and ceramics.

nents. [47-50] However there appears to be no ranking of ceramic particles in hip simulator models. Our two hypotheses in this study were that i) alumina particles would plow into $\mathrm{CoCr}$ surfaces creating scratches $>40 \mu \mathrm{m}$ wide, comparable to damage created by large $\mathrm{CoCr}$ particles [39], and ii) hydroxyapatite particles would produce very mild scratching on $\mathrm{CoCr}$ surfaces, comparable to the results with PMMA particles. [39,51]

\section{Methods}

Hydroxyapatite particles for our study were provided in powder form by two orthopedic vendors (Table 1). The flakes were scraped from retrieved Ti6Al4V femoral stems archived in the DARF Center. A ceramic vendor provided two alumina powders and we retrieved alumina flakes from a THA case that featured a fractured ceramic head. Size and shape distributions were determined by scanning electron microscopy (SEM: EVO MA15; Zeiss, Thornwood, NY). Energy dispersive x-ray imaging was used to characterize material types and to detect contaminants (EDS: Xflash detector 4010, Bruker AXS, Madison, WI). Particle numbers per $5 \mathrm{mg}$ allotments were determined mathematically using volume approximations and material densities (Table 1). Control data (PMMA and $\mathrm{CoCr}$ particles) were taken from a prior simulator study run under identical conditions.

The six 38-mm MOM bearings were wrought highcarbon, $\mathrm{CoCr}$ alloy, identical to those used in the prior study (DJO Global Company, Austin, TX). [39] Cups were mounted inverted in an orbital hip simulator (Shore Western Manufacturing, Monrovia, CA). [39,52] The simulator 


\begin{tabular}{|l|l|l|l|l|}
\hline Particle type & $\begin{array}{l}\text { Range } \\
(\mathbf{d i a})\end{array}$ & $\begin{array}{l}\text { Average } \\
(\mathbf{d i a})\end{array}$ & Ratio & $\begin{array}{l}\text { Particle } \\
\text { model (\#) }\end{array}$ \\
\hline $\mathrm{HA}$ powder-2 & $5-55$ & 21 & 0.17 & 370,000 \\
\hline $\mathrm{HA}$ flakes & $10-65$ & 23 & 0.19 & NA \\
\hline $\mathrm{HA}$ powder-1 & $5-60$ & 26 & 0.21 & 189,700 \\
\hline $\mathrm{Al}_{2} \mathrm{O}_{3}$ powder-1 & $5-80$ & 33 & 0.27 & 65,600 \\
\hline $\mathrm{Al}_{2} \mathrm{O}_{3}$ powder-2 & $5-170$ & 48 & 0.39 & 22,300 \\
\hline $\mathrm{Al}_{2} \mathrm{O}_{3}$ flakes & $5-330$ & 87 & 0.71 & 3,600 \\
\hline $\mathrm{CoCr}_{0}$ control & $45-180$ & 103 & 0.84 & 900 \\
\hline $\mathrm{PMMA}$ control & $30-250$ & 122 & 1.00 & 6,800 \\
\hline
\end{tabular}

Table 1. Ceramic particles ranked in order of size and compared to PMMA and CoCr controls

test mode used dynamic loading of $0.3-3 \mathrm{kN}$ for 10 simulator cycles (10-second test). Cleaning protocols were same as previous study. Only the femoral heads were characterized for roughness using white-light interferometry (WLI; NewView 600; Zygo, Middlefield, CT). Head roughness was compared using standard indices (Ra, PV) with 12 fields measured at each site. SEM and EDS imaging were used to study surface topography and detect contaminating elements. Surface scratches were characterized by their cross-sectional profiles ( $\mathrm{N}=12$ per site), noting widths and overall depth (Fig. 2: W, Z). Data analysis was performed by statistical review using one-way ANOVA and Dunn's multiple comparisons.

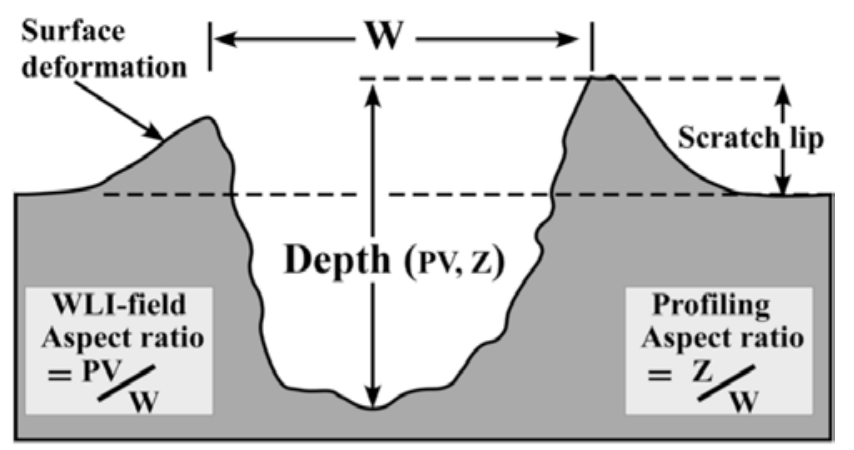

Fig2 Scratch Profile TH16

Figure 2. Profile showing scratch width $(W)$ and depth. For field data on scratch depths, roughness assessment used the peak-tovalley parameter $(P V)$ while profiles of individual scratches provided measurement-Z. The aspect-ratio comparisons used $P V / W$ and $Z / W$.

\section{Results}

Size range of the ceramic particles averaged smaller than either PMMA or CoCr controls (Fig. 3). Both types of HA powders presented spherical beads of size range 5-65 $\mu \mathrm{m}$ (Figs. 4a, b). The beaded morphology of alumina powder-1 (Fig. 5a: 5-80 $\mu \mathrm{m}$ ) appeared quite similar to the
HA powders whereas alumina powder-2 contained more irregular globular shapes with double the size range (Fig. $5 b)$. The particles collected from a retrieved ceramic case ranged still greater in size with some irregular fragments

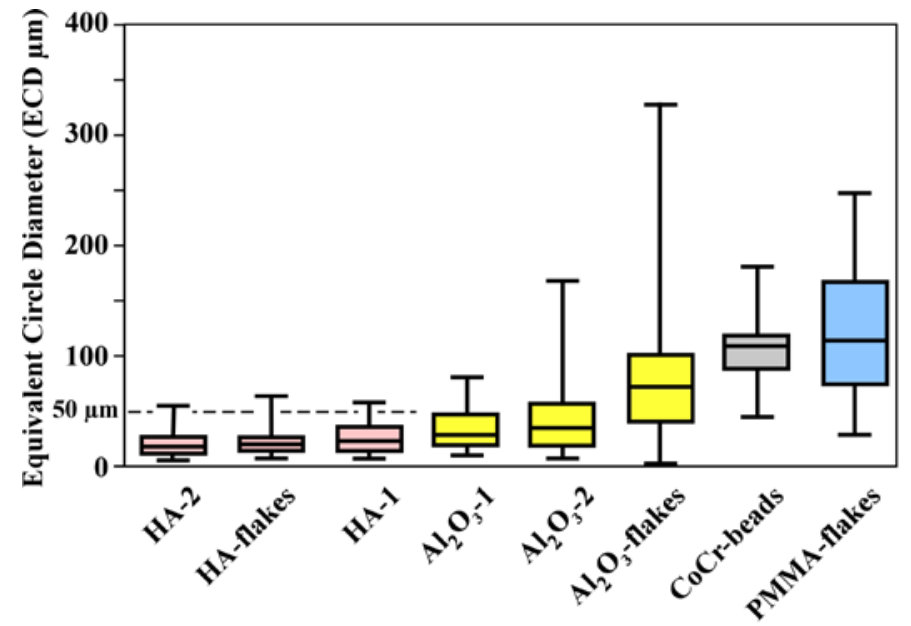

Figure 3. Ranking of particle sizes by equivalent circle diameter (ECD).

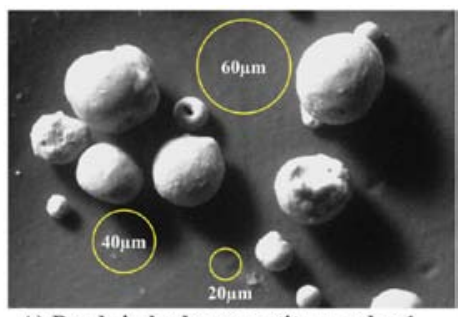

Figure 4. SEM imaging of hydroxyapatite beads in $(A)$ powder-1 and (B) powder-2.

A) Beads in hydroxyapatite powder-1

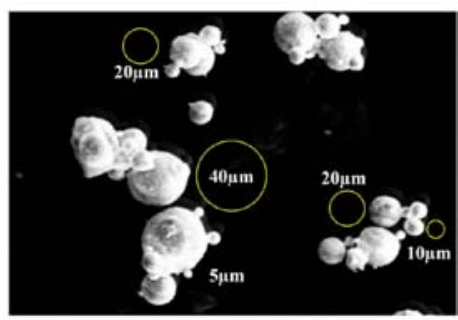

B) Beads in hydroxyapatite powder-2
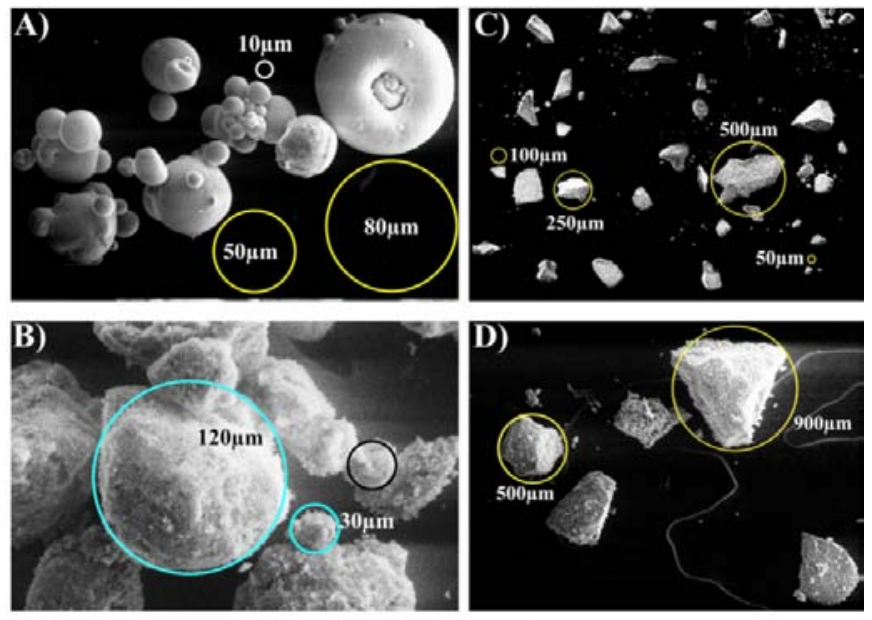

Figure 5. SEM imaging of alumina particles, (A) alumina powder-1, (B) alumina powder-2, (C) low magnification of alumina fragments, and $(B)$ alumina fragments of size $500-900 \mu \mathrm{m}$. 
(Figs. 5c) having with well-defined edges (Fig. 5d).

Surface-roughness ranking after the 10-second abrasion test revealed that bone cement and hydroxyapatite ceramics produced least damage on $\mathrm{CoCr}$ surfaces while the alu-

\begin{tabular}{|l|l|l|l|l|}
\hline Debris & Ra (nm) & $\begin{array}{l}\text { Ra } \\
\text { ratio }\end{array}$ & PV (nm) & $\begin{array}{l}\text { PV } \\
\text { ratio }\end{array}$ \\
\hline $\begin{array}{l}\text { PMMA } \\
\text { control }\end{array}$ & $11(7-19)$ & 1.0 & $340(131-725)$ & 1.0 \\
\hline $\begin{array}{l}\mathrm{HA} \\
\text { powder-1 }\end{array}$ & $14(10-20)$ & 1.3 & $362(256-453)$ & 1.1 \\
\hline $\begin{array}{l}\mathrm{HA} \\
\text { powder-2 }\end{array}$ & $17(9-30)$ & 1.5 & $551(244-994)$ & 1.6 \\
\hline $\mathrm{HA} \mathrm{flakes}$ & $54(34-89)$ & 4.9 & $1287(613-1805)$ & 3.8 \\
\hline $\begin{array}{l}\mathrm{CoCr} \\
\text { control }\end{array}$ & $203(38-628)$ & 19 & $2003(823-3721)$ & 5.9 \\
\hline $\begin{array}{l}\mathrm{Al}_{2} \mathrm{O}_{3} \\
\text { powder-1 }\end{array}$ & $365(143-630)$ & 33 & $2720(1378-4278)$ & 8 \\
\hline $\begin{array}{l}\mathrm{Al}_{2} \mathrm{O}_{3} \\
\text { powder-2 }\end{array}$ & $475(236-870)$ & 43 & $3291(1971-4635)$ & 10 \\
\hline $\begin{array}{l}\mathrm{Al}_{2} \mathrm{O}_{3} \\
\text { flakes }\end{array}$ & $532(127-1234)$ & 48 & $5897(3199-8034)$ & 17 \\
\hline
\end{tabular}

Table 2: Roughness indices measured on CoCr surfaces

mina ceramics produced most (Table 2: Ra). Hydroxyapatite and bone-cement particles provided minimal damage to $\mathrm{CoCr}$ surfaces, average ( $\mathrm{Ra}$ ) indices being typically less than $0.01 \mu \mathrm{m}$ (Fig. 6). The hydroxyapatite flakes created

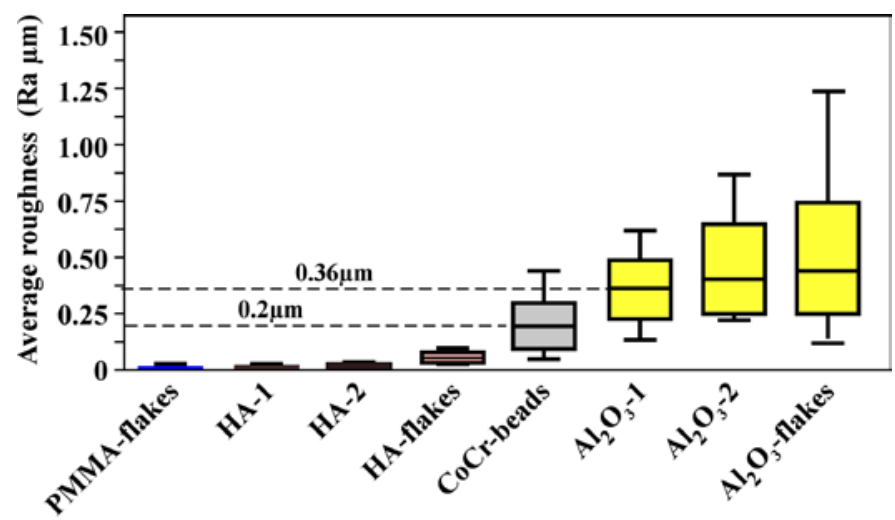

Figure 6. Ranking of CoCr surface damage (Ra: average roughness parameter) produced by particle types.

5-fold greater roughness than PMMA particles. Although suspected, particle imaging by SEM and EDS did not identify any metal contaminants $(\mathrm{Ti}, \mathrm{Al}, \mathrm{V})$. Alumina and $\mathrm{CoCr}$ particles raised surface roughness to greater than $0.2 \mu \mathrm{m}$ on average ( $\mathrm{Ra}), 19$-fold greater than produced by bone-cement particles. Maximum peak-to-valley roughness indices $(\mathrm{PV})$ provided similar damage ranking but with higher magnitudes (Fig. 7).

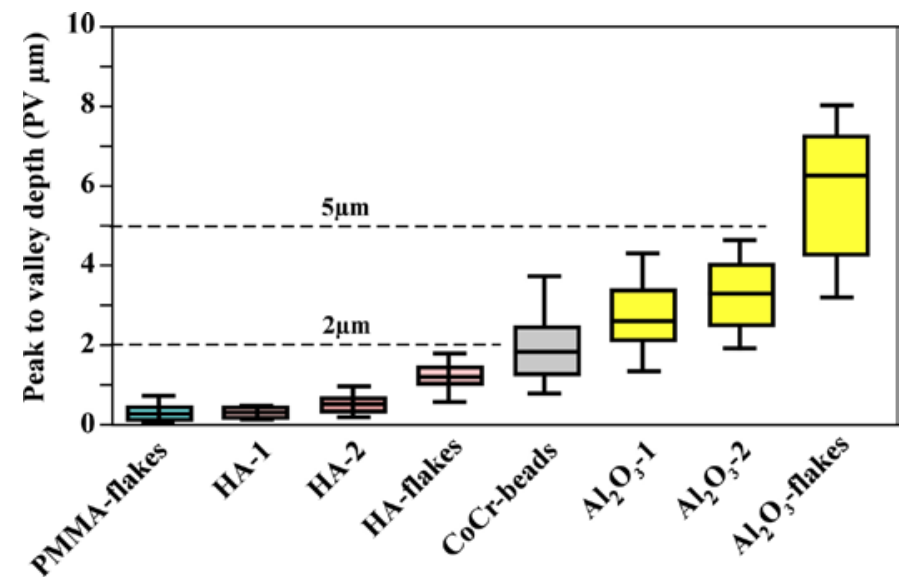

Figure 7. Ranking of CoCr surface damage (PV: peak-to-valley parameter) produced by particle types.

SEM imaging after 10 -seconds of abrasive wear with hydroxyapatite particles revealed $\mathrm{CoCr}$ surfaces that were typically featureless (background scratches $\pm 0.1 \mu \mathrm{m}$ ) with an occasional scratch $0.25 \mu \mathrm{m}$ deep in some fields of view (Fig. 8). In contrast alumina beads produced numerous scratches typically 20-80 $\mu \mathrm{m}$ wide (Figs. 9a, b) with occasional scratches up to $140 \mu \mathrm{m}$ wide by $3 \mu \mathrm{m}$ deep (Figs. $9 \mathrm{c}, \mathrm{d})$. These scratches averaged aspect ratios of 0.03 . Thus a $50 \mu \mathrm{m}$ wide scratch would typically have $1.5 \mu \mathrm{m}$ depth in the $\mathrm{CoCr}$ surface (Table 3). Equally conspicuous were $100-500 \mu \mathrm{m}$ size areas of surface contamination. These as verified by EDS were layers of pulverized alumina particles, ranging 1.2-1.9 $\mu \mathrm{m}$ thick on $\mathrm{CoCr}$ surfaces. Alumina flakes produced the greatest surface damage, with numerous large scratches $80-100 \mu \mathrm{m}$ wide surrounded by numerous pits (Fig. 10). There was also abundant evidence of pulverized alumina layers, typically adjacent to the larger scratches (Fig. 10b).

Sampling of individual scratches to characterize width

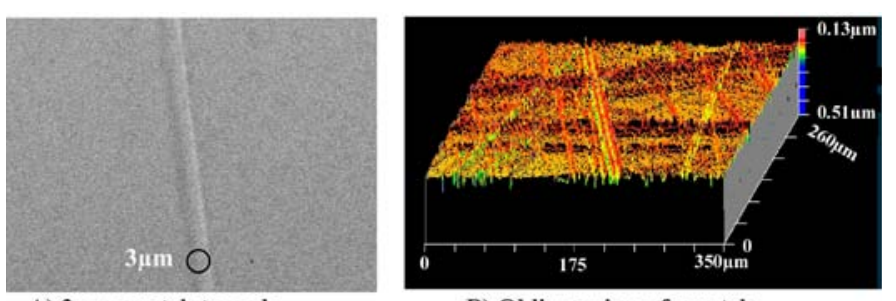

A) $3 \mu \mathrm{m}$ scratch to scale

B) Oblique view of scratch

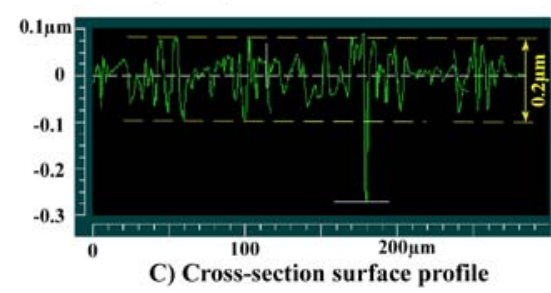

Figure 8. SEM and Zygo imaging of CoCr surface scratched during hydroxyapatite test, (A) surface scratch, $(B)$ oblique image of scratched surface, and $(C)$ profile of surface scratches. 


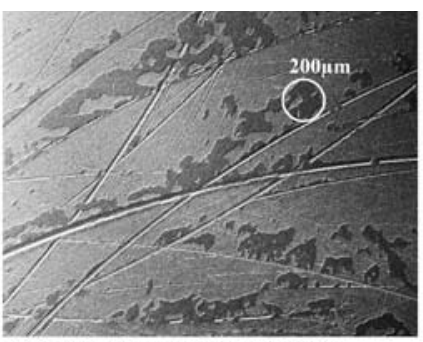

A) SEM image CoCr surface
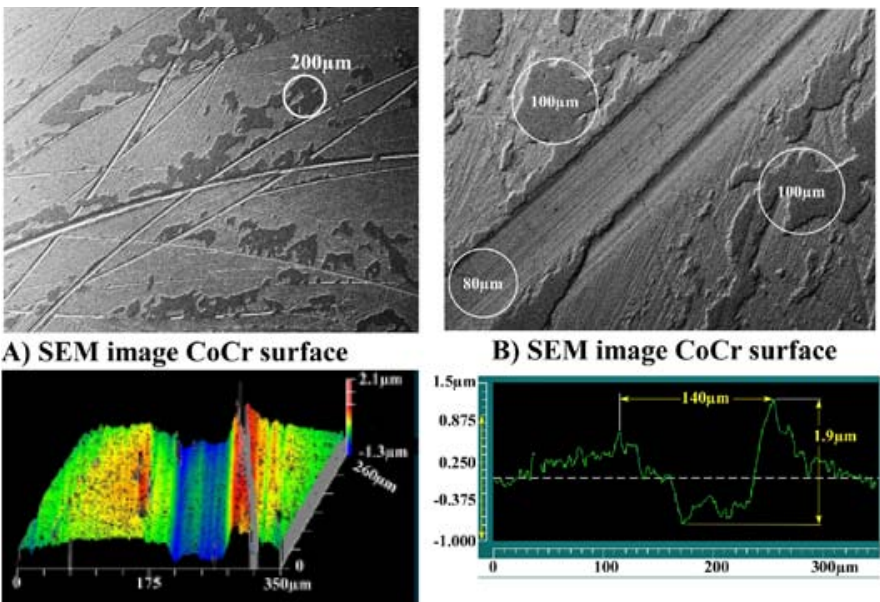

B) SEM image CoCr surface

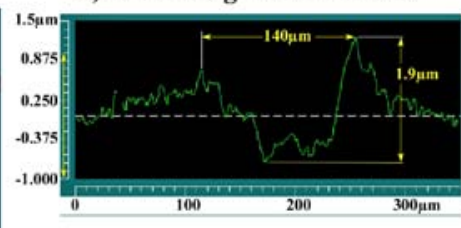

$\begin{array}{ll}\text { C) Interferometry image CoCr scratch } & \text { D) Cross-sectional profile }\end{array}$

Figure 9 SEM and Zygo imaging of CoCr surface scratched during

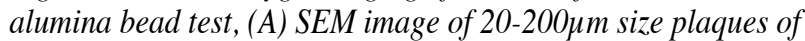
alumina contamination, (B) 80um wide scratch with 20-200 $\mathrm{\mu m}$ size plaques of alumina contamination, $(C)$ oblique Zygo image of scratched CoCr surface, and (D) large scratch profile.
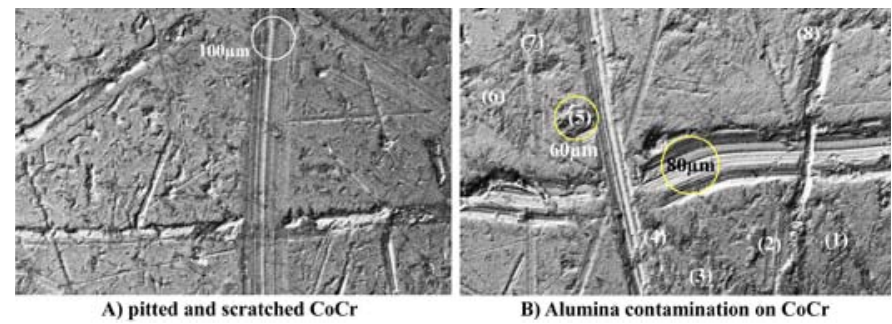

Figure 10. SEM imaging of CoCr surface scratched during alumina

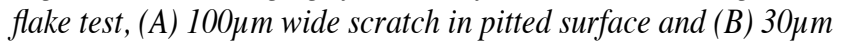
and $80 \mu \mathrm{m}$ wide scratches surrounded by plaques of alumina contamination (numbered 1-8).

\begin{tabular}{|l|l|c|c|c|}
\hline $\begin{array}{l}\text { Measure- } \\
\text { ments }\end{array}$ & Debris & $\begin{array}{l}\text { Lip width } \\
(\mathbf{W} \boldsymbol{\mu} \mathbf{m})\end{array}$ & $\begin{array}{l}\text { Scratch depth } \\
(\mathbf{P V} \boldsymbol{\mu} \mathbf{m})\end{array}$ & $\begin{array}{l}\text { Aspect ratio } \\
(\mathbf{P V} / \mathbf{W})\end{array}$ \\
\hline $\mathrm{N}=24$ & $\begin{array}{l}\text { PMMA } \\
\text { control }\end{array}$ & $\begin{array}{c}8 \\
(3-23)\end{array}$ & $\begin{array}{c}0.12 \\
(0.04-0.32)\end{array}$ & 0.02 \\
\hline $\mathrm{N}=12$ & $\begin{array}{l}\mathrm{HA} \\
\text { powder-1 }\end{array}$ & $\begin{array}{c}3 \\
(2-5)\end{array}$ & $\begin{array}{c}0.16 \\
(0.13-0.20)\end{array}$ & 0.05 \\
\hline $\mathrm{N}=12$ & $\begin{array}{l}\mathrm{HA} \\
\text { powder-2 }\end{array}$ & $\begin{array}{c}4 \\
(2-6)\end{array}$ & $\begin{array}{c}0.18 \\
(0.06-0.28)\end{array}$ & 0.04 \\
\hline $\mathrm{N}=12$ & HA flakes & $\begin{array}{c}12 \\
(5-28)\end{array}$ & $\begin{array}{c}0.73 \\
(0.14-1.37)\end{array}$ & 0.06 \\
\hline $\mathrm{N}=24$ & $\begin{array}{l}\text { CoCr } \\
\text { control }\end{array}$ & $\begin{array}{c}54 \\
(26-108)\end{array}$ & $\begin{array}{c}1.44 \\
(0.48-2.62)\end{array}$ & 0.03 \\
\hline $\mathrm{N}=12$ & $\begin{array}{l}\mathrm{Al}_{2} \mathrm{O}_{3} \\
\text { powder-1 }\end{array}$ & $\begin{array}{c}59 \\
(16-92)\end{array}$ & $\begin{array}{c}1.59 \\
(0.67-2.17)\end{array}$ & 0.03 \\
\hline $\mathrm{N}=12$ & $\begin{array}{l}\mathrm{Al}_{2} \mathrm{O}_{3} \\
\text { powder-2 }\end{array}$ & $\begin{array}{c}75 \\
(39-134)\end{array}$ & $\begin{array}{c}1.99 \\
(0.64-3.6)\end{array}$ & 0.03 \\
\hline $\mathrm{N}=18$ & $\begin{array}{l}\mathrm{Al}_{2} \mathrm{O}_{3} \\
\mathrm{flakes}\end{array}$ & $\begin{array}{c}54 \\
(13-98)\end{array}$ & $\begin{array}{c}4.97 \\
(1.58-11.21)\end{array}$ & 0.09 \\
\hline
\end{tabular}

Table 3: Profile measurements of scratches in surfaces of CoCr heads. and depth (Fig. 2. W, Z) revealed virtually the same ranking as the roughness indices provided by the interferometry assessment (Ra, PV). Scratch widths produced by bone cement and hydroxyapatite particles were the smallest and those produced by $\mathrm{CoCr}$ and alumina particles were the largest (Fig. 11). Similarly with scratch depths, bone cement and hydroxyapatite particles produced the shallowest scratches while $\mathrm{CoCr}$ and alumina particles produced the deepest damage (Fig. 12). Aspect ratio of profiled scratches (Fig. 2: ratio Z/W) produced by alumina and $\mathrm{CoCr}$ beads averaged 0.03 . The alumina flakes were noticeably different from the rest of the particles, producing a higher aspect ratio averaging 0.09 (Table 3 ).

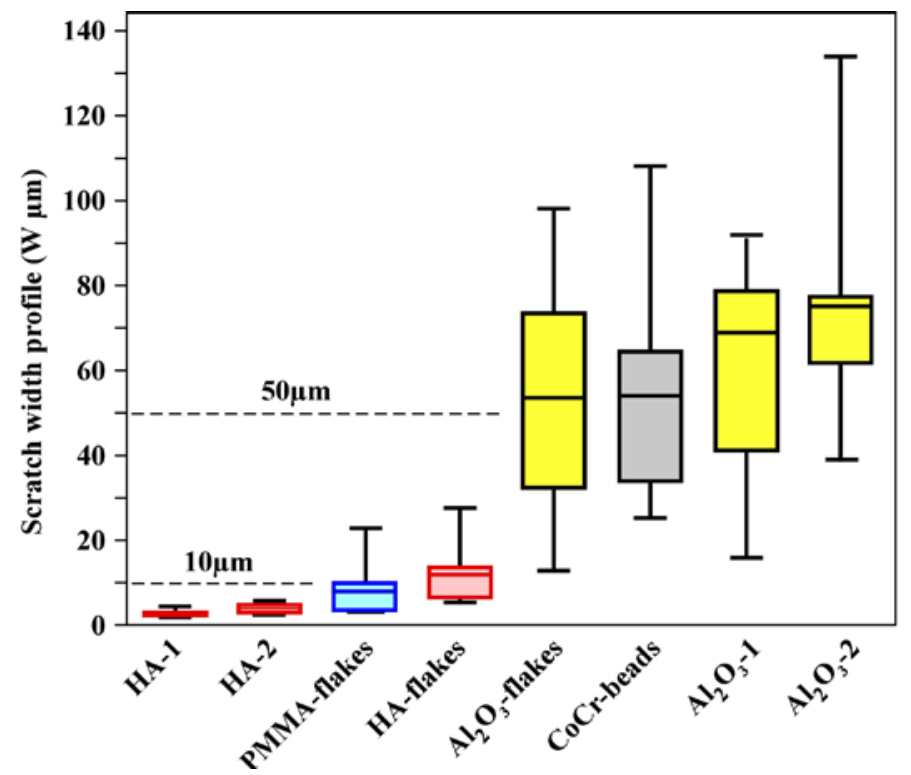

Figure 11. Ranking of scratch widths $(W)$ profiled individually at selected damage sites.

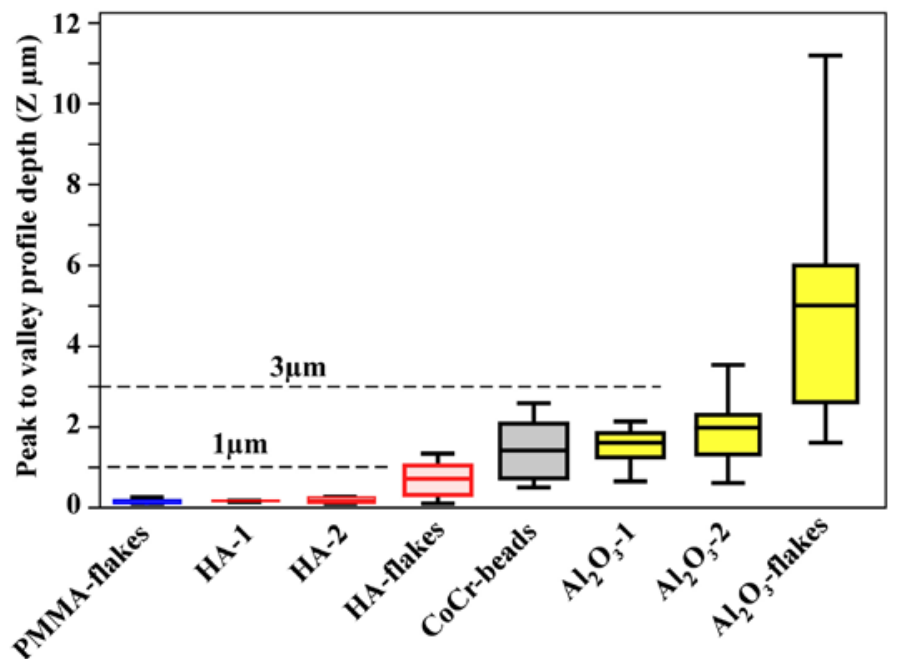

Figure 12. Ranking of scratch depths (Z) profiled individually at selected damage sites. 


\section{Discussion}

The risk of alumina particles scratching $\mathrm{CoCr}$ surfaces was clearly an anticipatable result. The new evidence was that such scratches typically had an aspect ratio averaging 0.03 , duplicating that created by metal particles. [39]. This conformity in surface damage supported our first hypothesis. The SEM data indicated that alumina beads typically $30-50 \mu \mathrm{m}$ in size were flattened massively within a 10-second test to produce $1-2 \mu \mathrm{m}$ thick ceramic layers on $\mathrm{CoCr}$ femoral heads. The larger alumina flakes reacted similarly, but with scratches having a somewhat higher aspect ratio (0.09). SEM imaging of these wide but shallow scratches indicated they were made by compressed plaques of alumina plowing across $\mathrm{CoCr}$ surfaces (Fig. 9). These data further illustrated the complexity of abrasion studies. The interaction of hip joint motion and applied contact stresses is a dynamic process that induces unpredictable fragmentation and wear mechanisms to circulating particles, even in alumina as the hardest biomaterial (Fig. 1). Thus the interaction of bearing type and debris compressive-strength adds additional complexity.

The hydroxyapatite beads did not damage $\mathrm{CoCr}$ surfaces due to a combination of low compressive-strength and hardness. This was not due to particle size or shape because a similar beaded morphology in alumina powder-1 produced dramatic $\mathrm{CoCr}$ scratches. This surprising result for hydroxyapatite particle revealed that this ceramic had no more effect than the large plastic particles that comprise bone cement. This result was in accordance with MOM simulator wear data. Liao et al (2010) ran a 5-million cycle study using a high concentration of hydroxyapatite particles and found no adverse effects. [31] Similarly it has been suggested that some commercial bone cements may be abrasive because they contain barium sulphate $\left(\mathrm{BaSO}_{4}\right)$ or zirconia ceramic $\left(\mathrm{ZrO}_{2}\right)$, such micron-size additives having three times the hardness of $\mathrm{CoCr}$ (Fig.1). $[55,56]$ Nevertheless several MPE simulator studies demonstrated that bone cement does not damage $\mathrm{CoCr}$ surfaces. $[34,36,37,57]$ We used a bone-cement slurry as the lubricant in a MOM simulator study and similarly found no adverse effect. [52] Therefore, these ceramic supported our second hypothesis, that hydroxyapatite debris would be no more damaging to $\mathrm{CoCr}$ surfaces than bone cement.

Prior abrasion models have primarily used metal-onpolyethylene (MPE) bearings. [13,36] Clinical studies indicated that, following revision of a fractured bearing, retained alumina debris could produce adverse wear of MPE. [54] Retrieval studies also indicated hydroxyapatite debris liberated from implant surfaces may accelerate polyethylene wear. $[43,44]$ However, use of MPE bearings in this 3rd-body wear study would have added additional complexity, the soft polyethylene surface allowing the particles to imbed in an unpredictable manner. Thus, use of MOM hip joints simplified the task of ranking ceramic damage to $\mathrm{CoCr}$ surfaces. Such laboratory models are further challenging due to uncertainties regarding choice of particulate morphology, dosage, and test methods. The major limitation in this study was that use of commercial ceramic powders lacked clinical relevance. It may be argued that the hydroxyapatite beads in powders- 1 and 2 differed in chemical and physical composition from hydroxyapatite particles released from implanted prostheses. It was also possible that the hydroxyapatite flakes scraped from the two retrieved femoral stems were contaminated by metal particles. This was not detected in samples scrutinized by SEM/ EDS but could not be ruled out for debris allotments used in the simulator studies. A further limitation in this study was that the fields of study could not be precisely duplicated between microscopic mapping with SEM and by interferometry. Thus quantitative results were presented only by the latter method.

Use of well-characterized and commercially available alumina and hydroxyapatite powders would appear advantageous in development of standardized abrasion tests. This 10-second simulator test established that alumina powders and fracture flakes damaged $\mathrm{CoCr}$ surfaces equally, indicating that such ceramic powders represent a valid test model. This may also be true for hydroxyapatite powders and flakes. However the evidence in this study was not considered conclusive.

\section{Acknowledgements}

Grateful thanks are due to R. Moran and P. Williams for their technical assistance. Recognition is also due $R \& D$ Group of DJO International (Austin, TX) for their donation of MOM implants. We are indebted to staff of Zygo Corporation's Western Regional Office, Tucson, AZ, for their technical support.

\section{Disclosure Statement}

One or more of our authors have disclosed information that may present potential for conflict of interest with this work. For full disclosures refer to last page of this journal.

References

1. Clarke IC, Lazennec JY, Brusson A, et al. Impingement and 3rd-body Wear Mechanisms with $28 \mathrm{~mm}$ MOM - A trigger mechanism for adverse wear in $\mathrm{CoCr}$ bearings. Clin Orthop Relat Res. 2013 (submitted). [PubMed] [CrossRef]

2. McMurtrie A, Abhijit R, Guha AR and Wootton JR. Loose Metasul liner causing partial amputation of the neck of the femoral component. Journal of Arthroplasty. 2009; 24: 159.e1 3. [PubMed] [CrossRef]

3. Heiner AD, Lundberg HJ, Baer TE, Pedersen DR, Callaghan JJ and Brown TD. Effects of episodic subluxation events on third body ingress and embedment in the THA bearing surface. J Biomech. 2008; 41: 2090-6. [PubMed] [CrossRef] 
4. Rodriguez JA. The squeaking hip is a multifactorial concern. rim impingement, microseparation, subluxation are all suspects in the sound generation. Orthopedics Today: 28 - 92 (2008). [Healio.com]

5. McPherson EJ, Clarke IC and Donaldson TK. Lesson learned from retrieval analysis of a dislocating, large diameter MoM revision THA - A case report. Reconstructive Review. 2012; 2: 10 -4. [CrossRef]

6. Bowsher JG, Donaldson TK, Williams PA and Clarke IC. Surface damage after multiple dislocations of a 38-mm-diameter, metal-on-metal hip prosthesis. J Arthroplasty. 2008; 23: 1090-6. [PubMed] [CrossRef]

7. Walter WL, Insley GM, Walter WK and Tuke MA. Edge loading in third generation alumina ceramic-on-ceramic bearings: stripe wear. J Arthroplasty. 2004; 19: 402-13. [PubMed]

8. Mellon SJ, Kwon YM, Glyn-Jones S, Murray DW and Gill HS. The effect of motion patterns on edge-loading of metal-on-metal hip resurfacing. Medical Engineering \& Physics. 2011; 33: 1212 - 20. [PubMed] [CrossRef]

9. Morlock MM, Bishop NE, Zustin J, Hahn M, Ruther W and Amling M. Modes of Implant Failure After Hip Resurfacing: Morphological and Wear Analysis of 267 Retrieval Specimens. J Bone Joint Surg Am. 2008; 90: 89 -95. [PubMed] [CrossRef]

10. Nevelos J, Ingham E, Doyle C, et al. Microseparation of the centers of alumina-alumina artificial hip joints during simulator testing produces clinically relevant wear rates and patterns. J Arthroplasty. 2000; 15: 793-5. [PubMed]

11. Leslie IJ, Williams S, Isaac G, Ingham E and Fisher J. High cup angle and microseparation increase the wear of hip surface replacements. Clin Orthop Relat Res. 2009; 467: 2259-65. [PubMed] [ㅁossRef]

12. Clarke I, Lazennec JY, Brusson A, Burgett M and Donaldson TK. Impingement and Abrasion Risks with $28 \mathrm{~mm}$ MOM - The trigger mechanism for adverse wear in $\mathrm{CoCr}$ bearings. Clin Orthop 2013 (submitted to Hip Soc. Awards 2013). [PubMed] [CrossRef]

13. Lundberg HJ, Liu SS, Callaghan JJ, et al. Association of third body embedment with rim damage in retrieved acetabular liners. Clin Orthop Relat Res. 2007; 465: 133-9. [PubMed]

14. Kligman M, Furman BD, Padgett DE and Wright TM. Impingement contributes to backside wear and screw-metallic shell fretting in modular acetabular cups. $J$ Arthroplasty. 2007; 22: 258-64. [PubMed]

15. Shon WY, Baldini T, Peterson MG, Wright TM and Salvati EA. Impingement in total hip arthroplasty a study of retrieved acetabular components. J Arthroplasty. 2005; 20: 427-35. [PubMed]

16. Hall RM, Siney P, Unsworth A and Wroblewski BM. Prevalence of impingement in explanted Charnley acetabular components. J Orthop Sci. 1998; 3: 204-8. [PubMed]

17. Yamaguchi M, Akisue T, Bauer TW and Hashimoto Y. The spatial location of impingement in total hip arthroplasty. J Arthroplasty. 2000; 15: 305-13. [PubMed]

18. Eickmann TH, Clarke IC and Gustafson A. Squeaking in a ceramic on ceramic total hip. In: Zippel H and Dietrich M, (eds.). Bioceramics in Joint Arthroplasty. Berlin, Germany: Steinkopff Verlag, Darmstadt, 2003, p. 187 - 92.

19. Clarke IC and Manley MT. How do alternative bearing surfaces influence wear behavior? $J$ Am Acad Orthop Surg. 2008; 16: S86-93. [PubMed]

20. Dennis DA, Komistek RD, Northcut EJ, Ochoa JA and Ritchie A. "In vivo" determination of hip joint separation and the forces generated due to impact loading conditions. J Biomech. 2001; 34: 623-9. [PubMed]

21. Komistek R. In vivo sounds of various total hip arthroplasty bearings. International Congress for Joint Replacements. Coronado, CA2012.

22. McKellop HA, Campbell P, Park SH, et al. The origin of submicron polyethylene wear debris in total hip arthroplasty. Clin Orthop. 1995: 3-20. [PubMed]

23. McKellop HA. Distinguishing among wear modes, wear mechanisms and wear damage in prosthetic joints. In: Streicher R, (ed.). Tribology and Bearing Surfaces in Total Joint Replacements. 2011, p. 103 - 13.

24. McHugh D, Currier J, Kennedy F, Collier J and Van Critters D. Plastic Deformation from Edge Loading is common on Retrieved Metal-on-Metal Hips and Can Be Predicted With Finite Element Analysis. In: Kurtz SM, Greenwald SA, Mihalko WM and Lemons JA, (eds.). Metal-On-Metal Total Hip Replacement Devices. 2013, p. 235-50. [ResearchGate] [CrossRef]

25. Clarke IC, Donaldson TK, Burgett MD, et al. Normal and Adverse Wear Patterns Created In-vivo on MOM Surfaces - a retrieval study representing four vendors. In: Kurtz SM, Greenwald SA, Mihalko WM and Lemons JA, (eds.). Metal-on-Metal Total Hip Replacement Devices. West Conshohocken, PA: ASTM International, 2013 p. 157-92. [ResearchGate] [CrossRef]

26. Howie DW, McCalden RW, Nawana NS, Costi K, Pearcy MJ and Subramanian C. The longterm wear of retrieved McKee-Farrar metal-on-metal total hip prostheses. $J$ Arthroplasty. 2005; 3: 350-7. [PubMed]

27. Kubo K, Clarke IC, Donaldson TK, et al. Wear Mapping analysis with retrieval $28 \mathrm{~mm} \mathrm{CoCr}$ CoCr Hip Bearings - 11 years Experience. J Bone Joint Surg Br. 2010; 92-B: 734-42.

28. Raimondi MT, Vena P and Pietrabissa R. Quantitative evaluation of the prosthetic head damage induced by microscopic third-body particles in total hip replacement. J Biomed Mater Res. 2001; 58: 436-48. [PubMed]

29. McNie CM, Barton DC, Fisher J and Stone MH. Modeling of damage to articulating surfaces by third body particles in total joint replacements. J Mater Sci Mater Med. 2000; 11: 569-78. [PubMed]

30. Lu B, Marti A and McKellop H. Wear of a second-generation metal-on-metal hip replacement effect of third-body abrasive particles. Trans Sixth World Biomat Congr. Kamuela, Hawaii2000, p. 183.
31. Liao Y-S, Swope S, Whitaker D, Vass S, Reimink M and Render T. Effects of 3rd body Hydroxylapatite (HA) Particles on the Wear Performance of $36 \mathrm{~mm}$ Ceramic-on-Metal (COM) and Metal-on-Metal (MOM) Hip Joint components in a Wear Simulation Study. 56th Annual meeting ORS 2010, p. 2325.

32. Parikh A, Hill P, Pawar V and Sprague J. Hip simulator wear testing of modular diffusion hardened oxidized zirconium couples. Orthopedic Research Society. San Antonio, Texas2013, p. 298.

33. Parikh A, Hill P, Pawar V and Sprague J. Long-term simulator wear performance of an advanced bearing technology for THA. Orthopedic Research Society. San Antonio, Texas2013, p. 1028.

34. Kubo K, Clarke IC, Sorimachi T, Williams PA, Donaldson TK and Yamamoto K. Aggressive 3rd-body wear challenge to highly crosslinked polyethylene: A hip simulator model. 17th International Conference on Wear of Materials. 2009, p. 734-42.

35. Pelt CE, Erickson J, Clarke IC, Donaldson TK, Layfield L and Peters CL. Histologic, Serologic, and Tribologic Findings in Failed Metal on Metal Total Hip Arthroplasty. AAOS Exhibit Selection. J Bone Joint Surg Am. 2013; 95 (21): 1-11. [PubMed] [CrossRef]

36. Wang A and Essner A. Three-body wear of UHMWPE acetabular cups by PMMA particles against $\mathrm{CoCr}$, alumina and zirconia heads in a hip joint simulator. Wear. 2001; 250: 212-6. [ScienceDirecet] [CrossRef]

37. Sorimachi T, Clarke IC, Williams PA, Yamamoto K and Donaldson TK. Third-body abrasive wear challenge of $32 \mathrm{~mm}$ conventional and $44 \mathrm{~mm}$ highly crosslinked polyethylene liners in a hip simulator model. J Eng in Med. 2009; 223 part H. [ResearchGate]

38. Bragdon CR, Jasty M, Muratoglu OK, O'Connor DO and Harris WH. Third-body wear of highly cross-linked polyethylene in a hip simulator. $J$ Arthroplasty. 2003; 18: 553-61. [PubMed]

39. Halim T, Burgett M, Donaldson TK, Savisaar C, Bowsher JG and Clarke IC. Profiling the third-body wear damage produced in $\mathrm{CoCr}$ surfaces by bone cement, $\mathrm{CoCr}$, and Ti6A14V debris: A 10-cycle metal-on-metal simulator test. J Eng in Med. 2014; Proc. IMechE 1-11. [PubMed] [CrossRef]

40. Bauer TW, Geesink RC, Zimmerman R and McMahon JT. Hydroxyapatite-coated femoral stems. Histological analysis of components retrieved at autopsy. J Bone Joint Surg Am. 1991; 73: 1439-52. [PubMed]

41. Bauer TW, Stulberg BN, Ming J and Geesink RG. Uncemented acetabular components. Histologic analysis of retrieved hydroxyapatite-coated and porous implants. J Arthroplasty. 1993; 8: 167-77. [PubMed]

42. Bloebaum RD, Bachus KN, Rubman MH and Dorr LD. Postmortem comparative analysis of titanium and hydroxyapatite porous-coated femoral implants retrieved from the same patient. A case study. J Arthroplasty. 1993; 8: 203-11. [PubMed]

43. Bloebaum RD, Beeks D, Dorr LD, Savory CG, DuPont JA and Hofmann AA. Complications with hydroxyapatite particulate separation in total hip arthroplasty. Clin Orthop. 1994 19-26. [PubMed]

44. Bloebaum RD and Dupont JA. Osteolysis from a press-fit hydroxyapatite-coated implant. A case study. J Arthroplasty. 1993; 8: 195-202. [PubMed]

45. Bloebaum RD, Lundeen GA, Bachus KN, Ison I and Hofmann AA. Dissolution of particulate hydroxyapatite in a macrophage organelle model. J Biomed Mater Res. 1998; 40: 104 14. [PubMed]

46. Bloebaum RD, Merrell M, Gustke K and Simmons M. Retrieval analysis of a hydroxyapatite-coated hip prosthesis. Clin Orthop. 1991: 97-102. [PubMed]

47. Krol R, Wiatrak A and Kaminski A. Management of fractures of ceramic heads in total hip arthroplasty patients. Ortop Traumatol Rehabil. 2007; 9: 429-35. [PubMed]

48. Ha YC, Kim SY, Kim HJ, Yoo JJ and Koo KH. Ceramic liner fracture after cementless alumina-on-alumina total hip arthroplasty. Clin Orthop Relat Res. 2007; 458: 106-10. [PubMed]

49. Toni A, Traina F, Stea S, et al. Early diagnosis of ceramic liner fracture. Guidelines based on a twelve-year clinical experience. J Bone Joint Surg Am. 2006; 88 Suppl 4: 55-63. [PubMed]

50. Habermann B, Ewald W, Rauschmann M, Zichner L and Kurth AA. Fracture of ceramic heads in total hip replacement. Arch Orthop Trauma Surg. 2006; 126: 464-70. [PubMed]

51. Liao Y-S, Swope S, Whitaker D, Vass S, Reimink M and Render T. Effects of 3rd body Hudroxylapatite (HA) particles on the wear performance of $36 \mathrm{~mm}$ Ceramic-on-Metal (COM) and Metal-on-Metal (MOM) Hip Joint Components in a Wear Simulation Study. ORS 56th Annual Meeting. 2010, p. poster 2325.

52. Halim T, Clarke IC, Burgett-Moreno M, Donaldson TK, Savisaar C and Bowsher JG. A Simulator Study of Adverse Wear with Metal and Cement Debris Contamination in metalon-metal (MOM) Hip Bearings. J Bone Joint Research (UK). 2015; 4: 29-37. [CrossRef]

53. Clarke IC, Lazennec JY, Smith EJ, Sugano N, McEntire B and Pezzotti G. Ceramic-on-Ceramic Bearings: Simulator Wear Compared to Clinical Retrieval Data. In: Sonntag R and Kretzer JP, (eds.). Materials for Joint Arthroplasty - Biotribology of Potential Bearings. Imperial College Press, 2015.

54. Kempf I and Semlitsch M. Massive wear of a steel ball head by ceramic fragments in the polyethylene acetabular cup after revision of a total hip prosthesis with fractured ceramic ball. Arch Orthop Trauma Surg. 1990; 109: 284-7. [PubMed]

55. Mishra AK and Davidson JA. Zirconia/Zirconium: A new, abrasion resistant material for orthopedic applications. Mater Tech. 1993; 8: 16-21.

56. Davidson JA, Poggie RA and Mishra AK. Abrasive wear of ceramic, metal, and UHMWPE bearing surfaces from third-body bone, PMMA bone cement, and titanium debris. Biomed Mater Eng. 1994; 4: 213-29. [PubMed]

57. Wang A and Schmidig G. Ceramic femoral heads prevent runaway wear for highly crosslinked polyethylene acetabular cups by third-body bone cement particles. Wear, 14th International Conference on Wear of Materials. 2003; 255: 1057-63. 